\title{
PUBLIC BROADCASTING: A MEDIUM IN SEARCH OF SOLUTIONS
}

\author{
JoHN W. MacY, JR.*
}

INTRODUCTION

In its simplest and most comprehensive definition, a communications system is a process in which creative communicators become aware of the expressed and sometimes unexpressed needs of the users of the system and responsively collect and provide information, entertainment, and other resources toward the satisfaction of these needs. Despite the often quoted and now popular belief that in electronic communications systems "the medium is the message," the design of a system in which the message is itself the message-and the medium is merely a means of delivering a diversity of messages of intrinsic value to the users-is a mandate for radio and television in the decade of the r97os. This is one of the basic philosophies behind the approach of the Corporation for Public Broadcasting (CPB) as it builds and develops the public sector of broadcasting.

Some time ago Robert Oppenheimer was quoted as saying, "What is new is new not because it has never been there before, but because it has changed in quality."2 This is surely what is new about the Corporation for Public Broadcasting. But to understand the nature and direction of the qualitative changes brought about by its creation and activities, it is necessary to look first at what was there before and how the Corporation came into being.

\section{I}

\section{Background of Public Broadcasting}

Over the past fifty years, the American public, through its elected representatives and otherwise, has made a series of choices to encourage the development of a public alternative in the field of communications. A review of these "choice points"3 shows an orderly historical progression to the development of a strong and viable public communications system, an evolution clearly reflecting the depth of the need felt for a harnessing of communications technology to the educational mission of society as well as for an alternative source of both informational and entertainment programming. From a variety of early nonprofit broadcasters, largely

- President and Chief Executive Officer, Corporation for Public Broadcasting, Washington, D.C.

${ }^{1}$ Cf. M. Malutian \& Q. Fiore, The Medium is the Message (1967).

${ }^{2}$ Ways, The Era of Radical Change, Fortune, May 1964, at Ir3, II5.

${ }^{B} \mathrm{~A}$ "choice point" is a point or period in time where society as a whole, through its representatives, makes a commitment of psychic, human, legal, and/or economic resources in a particular direction. The ensuing historical survey identifies many such choice points in the development of public broadcasting. 
educational institutions and civic-minded groups, a structured system of public broadcasting is emerging. Included in this system-and within the definition "public broadcasting" generally -are stations of these various kinds:

(I) School stations, licensed to school systems or school districts and brought into being primarily to serve elementary and secondary education;

(2) State stations, licensed to state boards of education or similar state agencies. These, too, have been brought into being to serve primary and secondary education and are frequently linked into state networks;

(3) University stations, licensed to public rather than private colleges and universities. They have been brought into being primarily as an extension of ordinary university activities, including continuing education; in some cases they are also used as instruments for instruction in television or communications; and

(4) Community stations, licensed to nonprofit corporations. These stations predominate in the large metropolitan areas, and in general are the largest and best-financed stations.

A. Radio

Radio was the first electronic broadcast medium when it came upon the scene in the rg2os. It expanded very rapidly in the decade of the r93os, reaching a peak in 1947. This medium faced the competitive onslaught of television beginning in about I948 and from I948 to I959 turned to music formats as its prime production. In the I $960 s$, radio, benefiting from a general expansion in the use of electronic media ${ }^{4}$ and particularly from the widespread use of the transistor, started on a new upswing.

The Radio Act of $19 \mathrm{I}^{5}{ }^{5}$ was the first domestic law for the regulation of radio, providing for the licensing of radio stations and operators by the Secretary of Commerce and the Secretary of Labor. Under its provisions public radio preceded commercial radio. In I9r9, what is now the oldest noncommercial station in the country, WHA in Madison, Wisconsin, was established, and, by 1925, I7I noncommercial stations were on the air. Commercial radio was also developing rapidly.

In 1927 Congress created the Federal Radio Commission, with regulatory authority to issue station licenses, to allocate frequency bands, to assign specific frequencies to individual stations, and to control the power of individual stations. ${ }^{6}$ As a result of Commission policies, only thirty-eight noncommercial stations remained on the air in 1937 .

With the creation of the Federal Communications Commission (FCC) in $1934{ }^{7}$

\footnotetext{
"In polls conducted in 1965 , it was reported that four out of five people interviewed cited broadcasting as the primary source of information and news. T. Tabackman, Historical Development of Broadcasting 2 (1969).

${ }^{5}$ Radio Act of 19I2, ch. 287, 37 Stat. 302.

- Radio Act of I927, ch. I69, 44 Stat. I 62.

${ }^{7}$ Communications Act of I934 $§$ I, 47 U.S.C. $\$$ I5I (I964).
} 
uniform regulation of commercial and noncommercial broadcasting was developed. The FCC quickly moved to secure mutual cooperation between public service and commercial broadcasters, but these efforts often met with defeat. In I938, the FCC, in introducing the new FM system of broadcasting, reserved space in the spectrum for the exclusive use of public broadcasters, ${ }^{8}$ and in 1945 the Commission located noncommercial broadcasting in the eighty-eight to ninety-two megacycle range, ${ }^{0}$ where it remains today.

The recent Public Radio Study, ${ }^{10}$ which was conducted by Sam Holt under a CPB grant, points out that public radio audiences are increasingly small and precisely defined. The Study also shows that public radio needs money and reorganization to create an effective noncommercial radio network.

Today radio is characterized by selective programming for selected audiences, and constant promotion of individual broadcast stations (over the airwaves and through print media) is the principal means of attracting large and loyal audiences. The Public Radio Study points out that nearly one-fourth of the waking hours of the average American are spent watching television or listening to radio. ${ }^{11}$ At the present time, there are twenty-five public radio stations on the AM band and 384 public radio stations on the FM band. This rapid expansion in the FM band has surpassed commercial FM growth.

\section{B. Television}

The first noncommercial television station went on the air in May 1953, when KUHT, licensed to the University of Houston and the Houston Board of Education, became the pioneer. In I960, when there were sixty-two public television stations, a national production entity, which later became National Education Television (NE'T), was created through Ford Foundation support. This was the beginning of the attempt to establish a national network of public television stations. Networking for the most part was provided by videotape and film distribution by airplane, with limited experiments with electronic interconnection of NET affiliates.

Beginning in 1962 with the passage of the Educational Television Facilities Act, ${ }^{12}$ strong federal support was given to the provision of equipment to noncommercial licensees. The original act provided for federal grants to assist licensees in construction of new stations or expansion of existing stations. It made federal funds available on a $50 / 5^{\circ}$ matching basis and directed that the federal share should be spent on interconnection projects. This landmark legislation is discussed in greater detail later in this article.

These developments set the stage for the appointment in 1964 by the Carnegie Corporation, with the encouragement of President Johnson, of fifteen distinguished

\footnotetext{
${ }^{8} 4$ FCC ANn. Rep. 66-67 (I938).

${ }^{\circ}$ I2 FCC ANn. Rep. r8-I9 (1945).

${ }^{10} \mathrm{~S}$. Holt, The Public Radio Study 237 (1969).

${ }^{11} I d$. at 22.

${ }^{12}$ Educational Television Facilities Act of 1962 , Pub. L. No. $87-447, \S 309$ et seq., 76 Stat. 64 .
} 
Americans $^{13}$ as a commission to study public broadcasting. The report of the Carnegie Commission on Educational Television ${ }^{14}$ was an exhaustive review of the system as they found it, its promise, and its opportunity. Their proposal formed the basis for the Public Broadcasting Act of 1967.15

Senator Magnuson introduced a bill on March 2, 1967 , which followed the Carnegie Commission proposals. It was greeted in both houses of Congress by strong support. Senator Pastore said, "The opportunity before the Congress and the challenge of this issue are of paramount importance for the future growth of this nation. It is an opportunity and a challenge that may be forever lost if we turn our backs against the proposition outlined in this legislation."16 On April II, I967, Congressman Claude Pepper, speaking during the debate on the Public Broadcasting Act, said, "At last the dream of the great medium of educational television has been realized. I hope these dreams can become a reality, the kind of reality that can use communications to erase ignorance."17

The Carnegie Commission report proposed to extend and strengthen educational television through the creation of a new institution called the Corporation for Public Broadcasting. Combined with the Carnegie Commission before Congress were the efforts of the Ford Foundation, the National Association of Educational Broadcasters, station managers, and others in support of the creation of the Corporation and extension of the Public Broadcasting Facilities Act.

President Johnson signed the Public Broadcasting Act into law on November 7, $x 96 \%$.

II

\section{The Public Broadcasting Act of ig67}

In passing the Public Broadcasting Act Congress explicitly changed the focus of educational television to public broadcasting, including both educational television and educational radio in a new organizational concept. The act provided an authorization of $\$ 9$ million for fiscal year 1968 . After appropriations hearings, however, no funds were released in 1968 , and only $\$ 5$ million were appropriated in fiscal year 1969 .

As a rundown of Title I of the 1967 act reveals: (a) it extended for three years the authority, originally provided under the ETV facilities legislation of 1962, for federal grants to assist in construction and expansion of public stations; $(b)$ it made

${ }^{13}$ The Commission chairman was James $R$. Killian, and the members were James B. Conant, Lee A. DuBridge, Ralph Ellison, John S. Hayes, David D. Henry, Oveta Culp Hobby, J.C. Kellam, Edwin H. Land, Joseph H. McConnell, Franklin Patterson, Terry Sanford, Robert Sauder, Rudolf Serkin, and Leonard Woodcock.

14 Carnegie Commission on Educhtional Television, Public Television: A Program for Action (1967).

${ }_{10}^{16} 47$ U.S.C. $\$ 390$ et seq. (Supp. IV, 1969).

${ }_{10}^{113}$ Cong. Rec. S7032 (I967) (remarks of Senator Pastore).

${ }^{17}$ II3 CoNG. Rec. 9092 (1967) (remarks of Representative Pepper). 
noncommercial educational radio stations eligible for assistance for the first time; (c) it established a maximum of $8 \frac{1}{2}$ per cent of the total appropriation as the maximum amount which could be awarded in any one state; $(d)$ it eliminated credit for existing equipment and increased to seventy-five per cent (from fifty per cent) the maximum allowable percentage of federal matching funds; and $(e)$ it eliminated restrictions on the federal share to be spent on station interconnection projects.

The impact of the facilities provisions has been considerable. By I967 $\$ 32$ million had been spent in building the ETV system under the earlier law. Since that time, annual appropriations of $\$ 4$ million per year have been granted for this purpose. One-hundred sixty-one grants have been made in forty-seven states, providing ninetytwo new stations and expanding sixty-nine others. The increased coverage is estimated to be in excess of fifty million viewers, bringing public television within the reach of seventy-five per cent of the U.S. population. The 1962 act effected a reduction in the number of states without public broadcasting service from fifteen to three.

Title II of the 1967 act provided for the Corporation for Public Broadcasting, which was to be established as a nonprofit corporation in the District of Columbia with a board of directors appointed by the President with the advice and consent of the Senate. Specific provisions of Title II gave the Corporation authority to make grants to local stations for production of programs and to defray other operating expenses. It directed the Corporation to make grants to production groups within and without public broadcasting to provide programming for a national network as well as for individual local stations.

In speaking about the Corporation's financing, Congress emphasized that it should function with maximum freedom and no governmental interference. In signing the Public Broadcasting Act into law, President Johnson called attention to the greatest fear by citizens, broadcasters, and the Congress: "Non-commercial television and radio in America, even though supported by Federal funds, must be absolutely free from any Federal Government interference over programming."18 This principle, incidentally, is the basis of the Corporation's current efforts to get long-range financing, rather than depending on annual appropriations.

The Corporation is not allowed under the act to own or operate its own facilities but is directed to provide programming with freedom, imagination, and initiative on the local and national level which would further the general welfare, be responsive to the interests of people locally and nationally, and provide diversity and excellence in quality. In addition to these activities, the Corporation is continuing to negotiate for interconnection of the stations with the American Telephone and Telegraph Company or any other appropriate communications carrier.

Title III of the 1967 act allocated $\$ 500,000$ for a study of instructional television ${ }^{10}$ by the Department of Health, Education, and Welfare. The Secretary of HEW

\footnotetext{
${ }^{18}$ Remarks of the President at the Signing of the Public Broadcasting Act, White House Press Rclease, Nov. 7,1967 .

${ }^{10}$ l.e., the uses of television in classrooms to supplement learning.
} 
appointed a distinguished commission for this purpose under the leadership of Dr. Sterling McMurrin, Dean of the Graduate School of the University of Utah and former U.S. Commissioner of Education. In its report the Commission recommended the creation of a National Institute for Education.

\section{III}

\section{ABCs of Public Broadcasting}

Many champions worked long and hard for passage of the Educational Television Facilities Act of 1962 and the Public Broadcasting Act of 1967 . These individuals and organizations were also instrumental in supporting FCC proposals for allocation of frequency and in generating private funds for support of public broadcasting. Limited descriptions of the principal participants in the development and operation of public broadcasting and recognition of their contributions are offered in the following paragraphs.

Citizen users. Private citizens provide money directly for support of local entities in public broadcasting, as well as indirectly through taxes paid to state and federal authorities in support of state and national entities and school-board-based systems. They also determine by their interests and preferences the needs that can potentially be satisfied by transmission of creative information, ideas, or skills by local, state, national, or school-based systems. Citizen users provide indirect measures of effectiveness of programming by the number who watch. Interesting programming meeting their needs and consistent with their aspirations is expected by citizen users.

Licensees. The focal point of the public broadcasting industry and any network is the licensee. As observers and reporters of local needs, they determine local programming. Licensees also serve as fund-raisers in the community and as sources of creative talent and ideas in programming.

Congress. Congress provides appropriated funds out of tax revenue for purchase of equipment to build the medium. It also provides funds for the budget of the Corporation for Public Broadcasting to encourage professional, worthwhile programming at the local, state, and national levels.

The federal executive. The executive branch of the federal government administers the grant program for facilities construction through the Department of HEW. Proposals to Congress for annual funding and long-range financing for the Corporation for Public Broadcasting are made by the executive branch, which also provides funds for program development to local, state, regional, national, and independent producers in the fields related to its interests.

FCC. The FCC licenses and regulates operational behavior of licensees in the "public interest," and determines spectrum allocations for both commercial and noncommercial broadcasters. It also has developed rules regarding "fairness" in programming on controversial issues. ${ }^{20}$

\footnotetext{
${ }^{20}$ See Red Lion Broadcasting Co. v. FCC, 395 U.S. 367 (I969).
} 
State governments. State legislatures provide money for facilities and instructional programming on the state and local level from money provided by taxpayers (citizen users). They measure the priority of noncommercial television against other demands for funding more firmly entrenched in the legislative process. Individual members evaluate use and acceptability of programming among intended beneficiaries.

Local governments. The local governments, including particularly school boards, provide contracts with local stations to use television or radio for instructional purposes. They provide money and audiences by purchasing necessary receiving equipment and, in addition, provide teaching personnel to stations for on-camera work.

Corporation for Public Broadcasting. This corporation is the fund raiser and depository for federal funding for broadcast programming. Its programming philosophy is based on national and local needs. The Corporation was chartered by Congress and is the national focal point for public broadcasting. It is responsible for building one or more systems of interconnection for educational radio and television stations, while encouraging diversity and excellence in programming.

Ford Foundation. This foundation believes in public broadcasting and has supported it with \$II million since I95I. It has been and is the premier source of funds and will probably continue to be for some time to come. Among other projects, the Foundation backed the innovational Public Broadcasting Laboratory experiment at National Educational Television.

National Educational Television. NET is the major national program production agency for public television, producing original programming of all kinds for national use and negotiating with foreign networks and production agencies for interchange of programs of major significance.

National Association of Educational Broadcasters. This group consists of station managers and has been a prime proponent of public broadcasting legislation. The association provides a program library and distribution services for radio and television stations, serves as a trade and professional association, and conducts an annual convention.

Joint Council on Educational Telecommunications. As a voice of several prestigious education associations in the country before the FCC, other federal agencies, Congress, and the Corporation for Public Broadcasting, the Council is an effective proponent of space reservation for public broadcasting.

National Citizens Committee for Broadcasting. This committee was formed to promote the cause of public broadcasting and acquaint all people with its goals nationally and locally, as well as to work for the improvement of programming on the commercial networks.

National Instructional Television Center. Actively involved in discovering 
effective means of using television and radio, the Center provides both instructional and continuing education material.

National Education Association. The Association's division of audio-visual instruction actively works to encourage use of television in classrooms and public television in general.

Regional networks. These range from the Eastern Educational Network, which is fully interconnected, to regional associations. They provide regional points of view and programming for public broadcasting.

Business underwriters. Private corporations provide money to stimulate programming locally, statewide, and nationwide. They receive equal credit with the producer on each show for which money is used, but they may not obtain editorial control of the content of programming, nor may they advertise an individual product. However, the corporate name is publicized. Business underwriters expect highly popular programming which will attract a maximum viewing group.

\section{IV}

\section{Actrvities of the CoRPoration}

As the newest addition to the foregoing list of members in the public broadcasting community, the Corporation for Public Broadcasting must coordinate the activities of the other members toward achievement of Congressionally designated goals. The Congressional purpose in the 1967 act has been rapidly pursued with the very limited appropriated funds available for fiscal year 1969 ( $\$ 5$ million). With those funds in addition to a million dollars each from the Columbia Broadcasting System and the Carnegie Corporation, \$25,000 from the United Auto Workers, \$2,000 from Saul Haas (a member of the Corporation's Board of Directors), and $\$ 720,970$ from the Ford Foundation for specific purposes, many grant programs have begun.

The first funds given to television were $\$ 10,000$ general support grants given to I2I television licensees and production centers. In making these grants the Corporation relied on the judgments of the station managements concerning their needs and priorities. An analysis of the grants indicates that sixty-two stations are using part or all of the grant for public affairs programming of a local nature. Twenty-nine stations are using part or all of the grant to promote the station and its programs directly or indirectly in an attempt to increase the flow of private funding. Other grants were used for cultural programming, children's programming, expansion of programming hours, and establishment of community advisory councils.

Regional networks also received grants. The Rocky Mountain Federation is using its grant to establish liaison with regional sources of funding. The Midwestern Educational Television Network established a new office of program development coordination to provide intraregional program development. The Southern Educational Network produced a regional public affairs program and began publication of a monthly newsletter. The Western Educational Network requested on a 
matching basis (three to one) a grant to establish a network headquarters in Los Angeles. Grants to the Central Educational Network are being used for the operating expenses of interconnection, distribution of news analyses and children's series, and the production of thirteen half-hour programs on regional problems. The Eastern Educational Network used its grant to purchase video tape necessary for wider dissemination of outstanding programs of member stations.

The largest television grants were given to support programming. Thirteen television stations were selected as winners in this competition, in which grants ranged from $\$ 15,000$ to $\$ 50,000$. A total of 103 projects were submitted for consideration. From the many approved grants, two are indicative of their direction: The station at Bowling Green, Ohio, received $\$ 36,243$ for four programs on the struggles of an American small town to preserve its way of life against the encroachment of urban society, and the station in Charlotte, North Carolina, received \$50,000 for a series of half-hour programs dramatizing black folklore.

In its first year of operation, the Corporation committed ten per cent of its program budget for radio projects. It also funded a detailed study of public radio which convinced us that there is need for substantial assistance if the 425 existing noncommercial radio stations are to be able to contribute to their communities. Under a project called "Sounds of Radio," awards were made to twenty-three stations of amounts ranging from $\$ 1,800$ to $\$ 5,000$. Recipients were chosen from ninety-nine proposals made by sixty-five stations. These grants are to be used to prepare documentaries on the life of native tribes of Alaska, to produce thirteen half-hour shows on exploring under the ocean, to broadcast a dialogue on urban problems, to report in depth the situation of the Indian in America, to provide "Action Line" services to help the people of Appalachia, to offer musical programming, and to explore consumer problems.

Film is becoming increasingly important as a means of expression that can easily be converted to the television screen. As a result the Corporation has actively supported individual film projects and has made general grants to the American Film Institute for the production of films for television.

The 1967 act directed the Corporation to provide one or more systems of interconnection among public television and radio stations. The Corporation has negotiated a trial interconnection with the American Telephone and Telegraph Company, involving $13^{8}$ stations two hours a night, five nights a week. We are now pursuing a more extensive network with the telephone company involving additional hours each day and a seven day broadcast week. In addition the Corporation has been cooperating with the National Aeronautics and Space Administration on the ATS satellite series, a series of experiments in transcontinental interconnections. These experiments began on January 4, 1970, and on February 17 , I970, the first live coastto-coast interconnection using satellites was relayed from South Carolina to Los 
Angeles for transmission. These experiments will run throughout the year in both radio and television.

The purpose of these systems is to provide rapid and efficient means of distributing programs to stations. Stations have no obligation to broadcast the material distributed to them by the interconnection system. There is no requirement that material be used at the time it is broadcast. This is a clear indication that editorial control resides with the local station manager and not with the Corporation or its production centers.

\section{$\mathrm{V}$}

\section{Alternative Futures for Public Broadcasting}

With this review of the past of public broadcasting, we are now prepared to consider the future of the medium and the areas where the Corporation for Public Broadcasting can provide leadership.

Programming is the most sensitive area in radio and television. The Corporation is faced with the broadest range of emotion-filled demands. On the one hand are the "liberals" who believe that the broadcasting medium is a tool for shocking the "establishment" into relevance. On the other hand are the conservative elements of the political spectrum who desire of this medium only good news about the status quo. Like any two-sentence definition, this one is general and misses all the variations between these extremes. Nonetheless, it gives the reader an idea of the bucking-horse problem that the Corporation for Public Broadcasting must ride. In order to get the flavor of the ride, I chaired a programming conference in June 1969 at the invitation of the Kettering Foundation. The conference brought together a highly diversified group representing public broadcasting, independent producers, the press, scholars, and nonbroadcasting business leaders. Many new ideas and directions were generated, and these are being followed up now by National Educational Television and individual stations.

In the final analysis, all programming for public broadcasting must serve the needs of the local public at the station level. This places a heavy demand on the boards of directors and managers of local stations. They must know their community intimately and reflect its needs accurately.

Many problems of a national nature should be covered nationally. In the fall of I 969 we started a national debate series (The Advocates) in prime time Sunday night. The show explores diverse points of view on a multiplicity of national problems. Due to the existence of interconnection, it will bring debaters from both coasts of America to television screens across the country. These simultaneous discussions would not be possible without the Corporation-negotiated interconnection.

In addition to the national debate series, other public affairs programming is receiving considerable attention. Wider coverage of the nation's capital will be accomplished by the establishment of a public affairs programming center in 
Washington, D.C. Details of the center, its management, and thrust are now being worked out.

Realizing the universal appeal of music, we are continuing to televise a series of concerts by great American orchestras in prime time. This is a follow-up to the highly acclaimed Sounds of Summer program that replaced the Public Broadcast Laboratory in Summer 1969 .

We have also provided the network for daily presentation of Sesame Street, the first production of the Children's Television Workshop. This program is directed at teaching pre-schoolers letters of the alphabet and numbers by using the commercial advertising techniques of animation, jingles, and so forth. We are also continuing as the network for the award-wininng Misterogers' Neighborhood. In the future, expanded resources will allow the Corporation to finance much more children's programming. This programming will not be limited to pre-schoolers but will include several elementary levels in after-school entertainment. By providing children's programming that teaches in a noninstructional mode, the full potential of both television and the children will be extended. Long-range future plans will lead eventually to development of a national program production entity for children.

Instructional uses of television are a powerful means of mass education. The Corporation, while awaiting the recommendations of the McMurrin Commission established by Title III of the 1967 act, did its own planning in this area. The future holds the potential for open universities, high schools, and grade schools conducted in the home with standard tests administered in the school system. These developments will aid university officials and local school boards in meeting expanded needs for facilities while reducing per pupil costs. It is conceivable that exceptional teachers in schools and regions could be used to teach many more students through the broadcast systems on a city, state, or nationwide basis.

Continuing education in trades, hobbies, and cultural appreciation is another of the possible programming futures for the Corporation. We are now evaluating an expanded role in continuing education.

One of the headline-producing social problems of America is the racial problem. Television is not viewed along color lines. Shows directed to specific audiences draw not only a large following from that audience but a considerable following from others. Public broadcasting has shown particular strength in attracting minority audiences. A recent Louis Harris poll in the boroughs of Manhattan indicates that between seventy and ninety per cent of a large sample of blacks watch WNDT's Soul program. ${ }^{21}$ In Los Angeles large audiences and favorable critical reviews are heard for Cancion de la Raza, a Spanish-language soap opera about life in the Los Angeles barrio. With this proven ability, public broadcasting will continue to serve the needs of minorities in order to help achieve racial understanding.

\footnotetext{
" ${ }^{21}$ Ferretti, Harris Polls Weigh Effects of Ethnic Programming, N.X. Times, July 4, 1969, at 43.
} 
In all programming areas, as the needs are demonstrated by the licensees, the Corporation will apply resources to meet them. In a r 965 research project, Charles Winick pointed out that psychological tests of neighbors who watched and did not watch public television made it clear to him that "aspirers" watch public television. ${ }^{22}$ If "aspirers" are the audience, even though programs are beamed at all Americans, needs will be determined by these viewers.

Whether or not the need for such "diversity and excellence" in programming can be met will ultimately depend on the solution of two major problems-financing and talent development.

\section{VI}

\section{Financing}

Although Hyman Goldin's accompanying article ${ }^{23}$ reviews in depth the financing available for public broadcasting, I think it is necessary to explore the alternatives now facing the Corporation.

Recommendation No. to of the Carnegie Commission report reads,

We recommend that Congress provide the Federal funds required by the Corporation through a manufacturer's excise tax on television sets (beginning at two per cent and rising to a ceiling of five per cent). The revenues should be made available to the Corporation through a trust fund. ${ }^{24}$

In the Senate hearing on the Ig6 67 act, the Ford Foundation proposed the establishment of a nonprofit corporation for the control and operation of a satellite interconnection system for television and radio, the proceeds of which might, under certain circumstances, benefit public broadcasting. ${ }^{25}$

In order to allow more time for discussion of the issues involved in long-range financing, Congress in passing the 1967 act requested the executive branch to formulate a long-range financing plan for the Corporation. On February 9, I968, President Johnson requested his Cabinet-level officials to come up with a plan, but no plan was submitted to Congress prior to the arrival of the Nixon Administration.

The Nixon Administration is now looking at several proposals. One such proposal is to create a public broadcasting fund along the lines of the Carnegie recommendation. In this fund would be deposited the proceeds from a two per cent excise tax to be imposed on radio and television receiving sets at the manufacturer or importer level. In addition to relying on deposits from the tax, the

\footnotetext{
${ }^{23}$ Winick, How People Perceive Educational Television: A Study in Contmunication, I965 J. Soc. Psich. 259.

${ }^{23}$ Goldin, Financing Public Broadcasting, in this symposium, p. 650.

at Carnegie Commission, supra note 14 , at 8.

${ }^{25}$ The Ford Foundation proposals were derived from an earlier study prepared for the Foundation by Dr. Joseph A. Pechman. See Possible Tax Revenues for Non-Commercial Television, Reply Comments of the Ford Foundation, Establishment of Domestic Noncommon Carrier Communications Facilities by Nongovernmental Entities, No. I6495 (F.C.C., filed Dec. I2, 1966).
} 
proposal introduces a matching-fund concept. Under this concept, federal funds would be appropriated on a two-for-one basis for all nonfederal contributions in excess of $\$ 50$ million. Estimates indicate that the tax would produce between $\$ 60$ and $\$ 70$ million and that the matching-fund measure would produce about $\$ 20$ million.

The hearings and debate leading up to the passage of the Public Broadcasting Act discussed the Carnegie and Ford proposals at length. The Ford proposal was discounted as impractical at the time due to the limited development of communications satellites.

In order to achieve the Congressional and executive purpose of keeping the Corporation free from political influence and government control of programming, the matching fund seems desirable. The excise tax places the responsibility for support with the set purchasers who have the largest potential benefit. The matching fund has provisions to isolate the Corporation from annual authorization and review. Tax proposals will meet substantial opposition, and therefore an alternative matching fund with multiple-year authorization and appropriation is also being considered by the Administration. Alternative futures in programming are directly related to the form of financing the Corporation can attract.

\section{VII}

\section{Talent Development}

The future and the alternatives available will depend largely upon the people in public broadcasting. Two programs were started in 1969 to encourage talent development. The Career Fellowship program asked stations to select locally available young people who had the potential to make a career in public broadcasting. From eighty-three recommendations from stations, fourteen fellows were selected. The Fellowship recipients are spending a year studying and working at stations in various phases of broadcasting-from administration to production. It is hoped that at the end of the year they will decide to stay in public broadcasting.

Our other fellowship program involves the selection of present employees to work overseas for a year at other publicly supported broadcasting facilities. Four fellows were selected this year for service with the BBC, CBC, Swedish Broadcasting Corporation, and the Japanese Broadcasting Corporation (NHK). After their year of study, the fellows will return to their local stations to share their experiences and new perspective.

The Corporation also provides grants for young filmmakers of the American Film Institute to produce films and commissions artists to produce original drama for television. This, in combination with support for various experiments in television, will make public broadcasting attractive to young creative talent in the future. 
ConcLusion

Public broadcasting, having passed through the numerous stages enumerated earlier in this paper, has a new beginning. The beginning is based on wedding a powerful medium to diverse educational messages. These messages of local and national origin are both instructional in the classroom sense and motivational in the individual involvement sense.

The Corporation for Public Broadcasting is moving in many directions to develop the potential in programming receivable through radio and television. It is encouraging the growth of the public needs and interest concept in broadcasting. To meet this public service orientation, the Corporation is funding programming at the national level while continuing to provide grants to local stations to augment their ability to respond to community needs. In both of these ways, the Corporation for Public Broadcasting will provide a medium in search of solutions. 